\title{
The possibilities and limits to dialogue
}

Dialogues in Human Geography 2018, Vol. 8(2) 109-123

(C) The Author(s) 2018 Reprints and permission: sagepub.co.uk/journalsPermissions.nav DOI: 10.1 I77/20438206/8780566 journals.sagepub.com/home/dhg

@AGE

\section{Reuben Rose-Redwood \\ University of Victoria, Canada}

\section{Rob Kitchin}

National University of Ireland, Ireland

\section{Lauren Rickards}

RMIT University, Australia

\section{Ugo Rossi}

University of Turin, Italy

\section{Ayona Datta}

King's College London, UK

\section{Jeremy Crampton}

University of Kentucky, USA

\begin{abstract}
In this article, we explore the nature, value, and challenges of dialogue both within and outside the academy. After considering the possibilities and limits to dialogue, we divide our analysis into three sections, first discussing dialogue as a form of embodied action, next examining dialogue as a means of enacting a critically affirmative politics, and finally exploring the challenges of engaging in dialogue as a way of practicing public geographies. In each case, we raise a number of questions concerning the potential of, and limitations to, dialogue in an age of increasing social tensions and political divides. We conclude by suggesting that although there are times when dialogical disengagement is warranted if the conditions of possibility for meaningful dialogue are unfulfilled, scholarly dialogue continues to play an important role in fostering spaces of mutual engagement in a polarized age.
\end{abstract}

\section{Keywords}

antagonism, debate, dialogue, political polarization, public geographies

\section{Corresponding author:}

Reuben Rose-Redwood, Department of Geography, University of Victoria, Victoria, BC V8N 3L2, Canada.

Email: redwood@uvic.ca 


\section{Introduction}

What are the conditions of possibility and limits to dialogue in human geography today? We pose this question at a time of increasing polarization and antagonism in social and political life, when the very possibility of meaningful dialogue across the fault lines of political divides is in question. To be sure, there is certainly no shortage of ideological exchange - thanks to the proliferation of social media-and some might even view the present moment as being characterized by an excess of dialogue, if the latter is broadly defined. Yet dialogue is not synonymous with two or more intersecting monologues or polemics; on the contrary, it presupposes the capacity to listen to, and engage with, one's interlocutors rather than treating them as 'an enemy ... whose very existence constitutes a threat' (Foucault, 1984: 382). This latter conception of the political as reducible to the friend/enemy distinction (Schmitt, 2007 [1932]) — problematic though it isappears to be alive and well in the 21 st century, and, as such, the value of 'dialogue must itself be critically interrogated' (Gurevitch, 2000: 89). In this article, we seek to stimulate open dialogue and debate over the very matter of 'dialogue' itself by posing a series of questions concerning dialogues in human geography and the geographies of dialogue more generally.

Academia is a crucible of debate and intellectual exchange with scholarly knowledge being constantly produced and contested. Many of us now produce collaborative knowledge in continuous dialogue with colleagues, whether as formal coauthors or in the spirit of collective praxis evident especially in feminist geography (Peake, 2016). However, scholarly exchanges can also be antagonistic and combative, particularly in contexts where neoliberal modes of university governance privilege competition and individual achievement among scholars at the expense of collaboration and communitybuilding. More broadly, the role of the university in society is perpetually being debated within and outside the academy, and it has long been entwined with the political events of the time, with academics acting as public intellectuals reflecting upon and analyzing contentious issues, advising various stakeholders, hosting public debates, and taking active roles in their local communities as advocates, activists, volunteer workers, elected politicians, newspaper columnists or contributors, and so forth.

Yet the role that universities and academics play in public dialogue is often framed in apolitical terms. This generally occurs when scholarly knowledge is portrayed as 'neutral' or 'objective' rather than inherently political. In the current political climate, however, it is increasingly untenable to claim scholarly 'neutrality', and scholars from different fields have become more explicitly and vocally engaged in public dialogue and debate as remaining silent or impartial on emerging situations becomes too damaging. In particular, since the 2016 US presidential election, controversies over White supremacists and other right-wing provocateurs engaging in hate speech and violence on university campuses across the United States remind us how the scholarly community is embroiled in the wider political currents of the day whether it likes it or not. The recent White supremacist violence and terrorist attack in the college town of Charlottesville, Virginia, on August 11-12, 2017, underscores the fact that university administrators, scholars, and students cannot simply stand aside and keep silent as fascists, neo-Nazis, and other White supremacist groups spread their message of hate and incite violence on university campuses and beyond. In such contexts, calling for more 'civil' dialogue hardly seems adequate to the task of confronting the dangers of the contemporary political moment. Indeed, movements such as 'antifa' (anti-fascist) demand more confrontational exchanges designed to destroy rather than respect fascist views.

These current flash points of antagonism within and beyond the academy, as well as the longer term conditions of scholarly exchange, raise a number of important questions for geographers and other scholars to consider. First and foremost, what are the conditions of possibility and limits to dialoguewhether scholarly or otherwise - and on what political, ethical, and affective basis should these be determined? When, if ever, should voices and opinions be excluded from scholarly debate? Are there legitimate circumstances for implementing a 'no platform' stance in academic environments for 
those advocating the politics of hate, discrimination, or violence (Bouattla, 2017)? This latter question has already been answered in the affirmative by many academic publishers, which have ethical codes of conduct that 'promote fairness and equality and oppose discrimination' (SAGE Publishing, 2018). Yet the recent controversy over the publication of an article espousing 'The Case for Colonialism' in the Third World Quarterly highlights the need for scholars, editors, and publishers to reaffirm a commitment to ensuring that there is no place in scholarly dialogue for promoting racist ideologies that legitimize or call for the subjugation of entire peoples (for a discussion of this controversy, see Flaherty, 2017; Robinson, 2017; Roelofs and Gallien, 2017; Thomas, 2017). Such speech is indeed legally protected in some countries - and rightly so-but this does not mean that it has any scholarly merit to justify its publication in well-respected academic journals, nor does the freedom of speech compel peer-reviewed journals to publish works that violate basic ethical standards of scholarly conduct.

In response to a petition with over 10,000 signatures calling for the retraction of 'The Case for Colonialism', the journal's editor defended its publication by insisting that the aim was to foster a 'balanced debate' (Qadir, 2017), and the journal's publisher stood by the editor's decision (Taylor and Francis Group, 2017). However, as one of the lead organizers behind the petition for retraction, geographer Farhana Sultana (2017), argues, '[e]ngaging with this piece does not advance our knowledge of colonialism or anything else ... Rather, it amplifies and emboldens horrific ideologies and practices to persist in academia and beyond'. Calling for a 'balanced debate' on the virtues of colonial domination, in other words, is comparable to publishing a piece on 'The Case for Genocide' or 'The Case for White Supremacy' and expecting scholars to seriously engage with such arguments as if they were legitimate scholarly positions. Framing scholarly debate in this way raises serious ethical issues, because such editorial decisions have the effect of normalizing racist-colonialist argumentation as a legitimate form of scholarly discourse.
The controversy surrounding the publication of 'The Case for Colonialism' therefore poses the following dilemma: If critics accept the terms of the debate and seek to engage in dialogue with its claims, the act of dialogical engagement itself further legitimizes the very discourse which critics view as illegitimate. Yet don't academics have an obligation to openly challenge racist ideologies masquerading as legitimate scholarship as well as 'alternative' facts and arguments that are counter to the public record or accepted expert knowledge? Or is a refusal to engage in dialogue justified in certain circumstances, and what implications does such a refusal have for ensuring that problematic or unsubstantiated claims are subject to critical scrutiny rather than being left unchallenged?

A similar dilemma characterizes the question of climate change. On the one hand, research indicates that in some situations constructive dialogue on the severity and implications of climate change is inhibited at the outset by the too-ready dismissal of, rather than engagement with, opinions that diverge from the mainstream (e.g. Howarth and Sharman, 2015), with the desire for consensus also papering over important disagreements (Gillard, 2016). On the other hand, attempting to engage with those skeptical of climate change can pose professional risks (Meldrum et al., 2017) and provide an opportunity for those opposed to climate change action to rehearse and amplify their reasons for rejecting such action (Hart and Nisbet, 2012). In the case of business and public sector leaders, it can also seem to necessitate the strategic adoption of a reductive and highly limiting economic rationale for action that implicitly endorses rather than challenges such economistic thinking (Rickards et al., 2014). Moreover, focusing on motivating specific actions among certain actors can stymie the need for broader political contestation and debate (Brulle, 2010).

Of course, dialogue is not the only way to critically engage with others' arguments or actions, nor is it necessarily always the most effective form of critical engagement (for an incisive critique of the call for rebuttal, see Jago, 2017). Indeed, calls for dialogue can be, and often are, used as a tactic for containing resistance by giving the appearance-and only the appearance-of 
democratic participation in public discourse and decision-making (Janz, 2015), while moving from talk to action opens up a whole range of other challenges. At the same time, dialogue can also be weaponized and used as a tactic of harassment, intimidation, and symbolic violence, particularly through the use of social media.

Put simply, dialogue does not take place in a vacuum but within specific and continually changing contexts, which raises questions about the terms and terrain upon which dialogue takes place and is conducted. Different media such as academic articles, newspaper op-eds, radio, television, and social media are conducive to different styles of interaction and argument, and they are shaped by different rules of engagement, which are also mediated by who controls those rules and their enactment. Sometimes academics get to control the terms and terrain as well as what questions are asked and how they are framed, as with seminars and conferences on campus or organized through professional organizations; other times they are beholden to others who frequently have a different agenda.

What, then, is the value of dialogue in human geography, within the scholarly community more generally, and beyond the academy in public and media forums? Given that the primary aim of Dialogues in Human Geography is to 'stimulate open and critical debate on the philosophical, methodological and pedagogical foundations of geographical thought and praxis', we as the journal's editors firmly believe that scholarly dialogue plays a vital role in opening a space to "critique present thinking and praxis' as well as debate 'future avenues of geographic thought' (Dialogues in Human Geography, 2018). Yet what is the broader purpose and value of scholarly dialogue in the present moment? Is the goal to ultimately reach consensus through rational deliberation, or is it to acknowledge that dissensus is inherent to scholarly and political endeavors, with dialogue then serving as a means of critically and constructively engaging with difference and disagreement? We subscribe to the latter view and suspect that most readers of this journal do as well, yet, in either case, what sort of ethics and politics should inform dialogical encounters in human geography? How might we balance the need for 'critique' with an 'affirmative politics' based upon 'a collective project valuing potential and possibilities' (Moss, 2014: 803)? What is the relationship between dialogue and doing, talk and action, in academia today? And how do we engage in dialogue with media and political actors, and the public more generally, in an age of 'post-truth' politics, 'fake' news, 'alternative' facts, and armies of trolls using social media to shout down and abuse those who hold different positions from themselves?

These are by no means easy questions to answer, but they are also difficult to avoid and necessary to ask. Below we suggest that in answering such questions, it is crucial to conceive of scholarly dialogue as a form of embodied action, to envision a critically affirmative politics of dialogical encounter, and to acknowledge the limits to dialogue and the importance of dialogical disengagement when the conditions of possibility for meaningful dialogue are unfulfilled.

\section{Scholarly dialogue as a form of embodied action}

Scholarly dialogue-indeed all dialogue - is an embodied practice, replete with its own power asymmetries and social hierarchies of class, race, gender, sexuality, age, (dis)ability, language, and geographical location (Underhill-Sem, 2017). How, then, have these axes of difference shaped dialogues in human geography? In answering this question, some geographers have called attention to 'how particular voices and bodies are persistently left out of the conversation altogether', particularly 'women, people of color, and those othered through white heteromasculine hegemony' (Mott and Cockayne, 2017: 2; also, see Women and Geography Study Group, 1997; McKittrick, 2006). Indeed, over the past three decades, there has been significant work done by geographers drawing on feminist, postcolonial, and queer theory to challenge masculinist, misogynist, heteronormative, ableist, colonial, and racialized modes of geographical scholarship (Bell, 1995; Derickson, 2017; Kobayashi and Peake, 1994; Mahtani, 2014; Robinson, 2003; Rose, 1993). Such work has encouraged geographers to be more reflective of, and attentive to, their own situatedness, 
positionality, and political praxis and has actively reshaped how geographers perform particular subjectivities through their writing and research as well as in classrooms, conference sessions, faculty meetings, and so on. Most recently, there has been a concerted effort to think through and enact a decolonization of the discipline, the theme of the Royal Geographical Society-Institute of British Geographers (RGS-IBG) conference in 2017, reflecting current debates happening across campuses and on the streets in North America and Europe (Esson et al., 2017). Others have highlighted the dominance of English as a medium of 'international' scholarly communication, which underscores how the very language in which scholarly dialogue takes place involves its own geographies of power (GarciaRamon, 2004). To approach the question of dialogue geographically, it is therefore important to ask: What are the spatialities of scholarly dialogue? How is dialogue situated in specific locations, how does it circulate, and what are the constraints on its circulation (Beer, 2013)? How do networks of scholarly dialogue produce, and reinforce, the centrality of some voices, bodies, and locations of knowledge production at the expense of others?

By conceiving of dialogue as a form of embodied action, we can better understand how scholarly exchanges are not confined to the textuality of the written word alone but also occur in both formal and informal settings at academic conferences, departmental meetings, workshops, colloquia, classrooms, reading groups, and outside the academy in media studios, stakeholder meetings, political debates, and rallies. The use of online digital media, such as blogs and social media, is also creating new spaces for dialogue among scholars as well as between scholars and wider publics (Kitchin et al., 2013; Longhurst, 2017; Rose, 2016; Wilson and Starkweather, 2014). As web-based modes of interacting at a distance reshape scholarly life, how are these new modes of interaction changing the qualities and quantities of scholarly dialogue? In what ways do such digital technologies enable and constrain scholarly discourses and practices? To what extent do they meaningfully extend scholarly ideas and knowledges beyond the academy?
Despite the proliferation of digital media, academic conferences remain a primary space of scholarly dialogue. The informal 'backstage' conversations that occur between sessions, after-hours over dinner or drinks, or while waiting for a flight home at the airport, are often just as important - if not more so - than the formal 'front stage' dialogues at paper and panel sessions. Some scholars, however, are excluded from many of these informal forums, and others are excluded from conference events altogether due to the prohibitive cost of international travel, family or teaching commitments, or as a result of discriminatory travel restrictions. For instance, a number of geographers were denied visas to enter the United States to attend the 2017 American Association of Geographers (AAG) conference in Boston due to the 'extreme vetting' associated with the Trump administration's Muslim travel ban. In response, some conference attendees protested in a public square near the conference (ACME Resistance, 2018), while others boycotted the AAG meeting in solidarity with those excluded from attending the conference, all of which drives home the point that scholarly dialogue does not occur in a political vacuum disconnected from the geopolitical forces in the world at large.

The university classroom is also an embodied space of dialogical encounters, although it has traditionally served as a monological space in which professors were thought to bestow established knowledge upon students. The limits to monological forms of pedagogy are now widely recognized, yet the turn toward dialogical pedagogies comes with its own challenges. For instance, while fostering critical discussion is often a pedagogical goal, what is the appropriate response when classroom discussions cross a line from legitimate disagreement to disrespectful attack? If students - or professors, for that matter-espouse racist, sexist, and other discriminatory positions, or make the equivalent of 'The Case for Colonialism', in class discussions, this will likely generate a forceful counter-response from other students. In these circumstances, adopting a neutral-pluralistic view that frames such discussions as a 'balanced debate' has the unacceptable effect of legitimizing discriminatory ideologies.

Although the limits to scholarly dialogue are real and have serious consequences, geographers have 
nevertheless engaged with the notion of dialogue in a variety of ways (Demeritt and Dyer, 2002). Most scholarly dialogues in geography typically occur within the interpretive communities of specific disciplinary subfields, yet there have been some attempts to 'stage' dialogues between different subfields as well as across the human/physical geography divide (Barry and Maslin, 2016; Daniels and Bartlein, 2017; Friess and Jazeel, 2017; Harrison et al., 2004; Lave et al., 2014; Mansfield and Doyle, 2017; Massey, 1999; Tadaki, 2017). In a recent forum published in the Annals of the American Association of Geographers that brings into dialogue pairs of geographers from different subfields, Domosh (2017) calls for a 'radical intradisciplinarity' with the aim of exploring 'what work we could do in the world when different and multiple ways of understanding come into conversation with each other'. She argues that intradisciplinary dialogue has the potential to find 'commonalities' as well as 'productive differences' and that constructively engaging in 'difficult conversations' across epistemological, ontological, and political divides is essential to the vitality of the discipline (Domosh, 2017: 2). In doing so, Domosh maintains that we must avoid the pitfalls of what Barkan and Pulido (2017: 39) refer to as 'easy pluralism' by not shying away from, or smoothing over, 'hard disagreements' but instead providing a 'space for conversations across the traditional boundaries of knowledge production' (Domosh, 2017: 1-2). Similarly, difficult conversations are required beyond the academy with respect to media work and exchanges on social media (Kitchin et al., 2013; McLean and Maalsen, 2013). Yet, again, what are the limits to engaging in 'difficult conversations', especially when mutual respect between interlocutors is lacking?

Although she does not draw explicitly on Mouffe's (2013) conception of agonism in advocating for the radical potential of geographical dialogue, Domosh's (2017: 2) embrace of a 'difficult pluralism'-like Sheppard and Plummer's (2007) call for 'engaged pluralism' - has many affinities with the 'spirit' of agonistic politics. An agonistic conception of dialogue rejects the ideal of universal consensus and instead acknowledges that dissensus is constitutive of political life. The best we can hope for, according to Mouffe (2013: 8), is to achieve a 'conflictual consensus' in which there is broad agreement on the conditions of possibility, or 'rules of the game' (Mouffe, 1993: 4), for dialogue even if many dialogues themselves are riddled with strong disagreements (also, see Natter, 2001). Yet-to engage with Mouffe on this - is the belief in the existence of a foundational consensus over the conditions of possibility for scholarly dialogue itself wishful thinking? In other words, aren't the most profound disagreements in academia precisely over what should serve as the foundational values of scholarly discourse and practice in the first place, and who has the power and authority to set the terms of debate?

Scholarly dialogue in geography has never been reducible to a 'civilized process of argument and counter-argument', since it also involves 'workplace and personal antagonisms [that] often become hopelessly entangled in real-life disputes' (Dear, 2001: 8). In its extreme forms, these antagonisms can take the form of everything from hate mail (Dear, 2001) to personal harassment (Valentine, 1998), or worse. This is even more so outside the academy, as media work via newspaper op-eds, radio interviews, and television appearances can lead to abusive messages and trolling in online comment threads as well as exchanges on social media that can descend into hateful abuse and 'flame wars' (Kitchin et al., 2013). In relation to media work, such exchanges are seen as part of the cut and thrust of public debate and an aspect of the entertainment of viewing/listening. Yet women and minorities are more likely to receive hateful responses online, including being threatened with sexual and physical violence designed to offend, intimidate, and silence them. This not only leads to a closure of dialogue but can produce forms of self-censure. Geographers have only begun to critically examine the social geographies of cyberbullying (Liu and Sui, 2017), and the need for critical scholarship on the digital geographies of hate, intimidation, and harassment will only increase in the foreseeable future. At the same time, it is also crucial to envision new forms of critically affirmative politics for constructively engaging in scholarly dialogue and debate. 


\section{Envisioning a critically affirmative politics of scholarly dialogue}

Spaces of dialogical encounter are potential sites of conviviality and mutual aid, yet they can also be arenas of conflict, struggle, and antagonism. Within the field of geography, such encounters are often framed in terms of conflicting 'paradigms' of geographical thought, but they also involve forms of careerist self-promotion, settling scores among warring factions, and personal feuds between individual scholars. How, then, do interpersonal relations among geographers affect dialogues in human geography? In what ways do social networks of personal friendship and acquaintance, as well as relations of enmity, between scholars influence the production of geographical knowledge? How does the social life of academia shape the affective atmospheres and emotional experiences of geographical dialogue? Put simply, in what sense can we speak of 'life in the conversational spaces of academic geography’ (Daniels and Bartlein, 2017: 29)?

If interpersonal relations and social networks facilitate scholarly dialogues, they also have the potential to create exclusionary barriers of entry for those who are not as well connected. This may take the form of everything from exclusionary patterns of scholarly citation to preferential treatment in hiring decisions (Mott and Cockayne, 2017). In fact, there is a whole world of scholarly dialogue that remains largely invisible to the public eye yet has a profound effect on which dialogues are rendered visible for public consumption. In particular, the peer-review process and editorial deliberations generally take the form of a series of behind-the-scenes dialogues and debates over what constitutes a legitimate form of scholarly discourse (Smith, 2006). These dialogical exchanges are often 'invisibilized' when a given paper is eventually published-with brief traces of these prepublication discussions appearing in acknowledgement sections or the occasional footnote that makes some reference to a reviewer's critique. To foster a more constructive dialogical exchange during the peer-review process, some journals have opted for 'open' peer reviews, among other possibilities, yet these alternative modes of review present their own challenges.
Additionally, dialogue may be stifled within social networks as interpersonal considerations dampen scholars' capacity or willingness to think or talk outside the accepted doxa of their group, and the fear of a backlash may restrain scholars from seeking to air their views both within and beyond academia. In varying degrees, all of us care about how others perceive and treat us, and we are all party to shared ideological commitments that strongly shape what we implicitly understand to be acceptable or unacceptable to say. Like the general media, very different outlooks on the world are cultivated in different academic groups and publishing outlets. With so much to read and so little time, we all look for excuses to focus on only that which seems most relevant at first glance. While pragmatic, this practice carries the risk of blinding us to the limitations of our current approach and cutting off potentially valuable critique. When engaging in dialogue with scholars from different disciplines or schools of thought, it is also important to avoid simplistically extracting tidbits from other scholarly areas with limited acknowledgment or recognition of the intellectual commitments associated with them (Rickards, 2015). It is in this context that the efforts of environmental geographers such as Tadaki (2017) to introduce into physical geography dialogue about the social production of science, while calling out simplistic social science understandings of science, are so remarkable (also, see Lave et al., 2014).

Divisions and bonds among scholars, of course, are not eternally fixed in the form of crystallized 'natural' boundaries; rather, they are relationally produced through a diverse range of boundarymaking practices. A variety of dividing and unifying strategies are commonly employed in dialogical encounters. One dialogical strategy is to actively minimize the differences between a collective 'us' in order to work toward building a united front against what is perceived as a 'common' threat. For instance, some radical geographers have sought to downplay differences within radical circles in order to find common cause against neoliberal capitalism (Harvey, 2017), whereas others have argued that radical geographers should cultivate spaces where disagreements within radical geography can be vigorously debated (Springer, 2017). For those seeking 
Left Unity, such critiques within progressive circles may be 'perceived as killing joy and solidarity', yet, as feminist geographers remind us, 'internal and intersectional critiques and related emotions might strengthen, rather than sink, needed progressive efforts' (Parker, 2017: 326).

Given the antagonistic, but also self-selective, politics of academia, what sort of 'ethics of discussion' (Natter, 2001: 31) or 'dialogic imagination' (Bakhtin, 1981) might geographers draw upon to constructively engage with critical tensions and interpersonal conflicts? Cultivating an 'ethic of care' (Lawson, 2007: 3) is certainly crucial, but it is also important to do so without glossing over real or needed disagreements in both theory and practice. If the 'critical' and the 'affirmative' are both essential to dialogue, it seems counterproductive to conceive of them as mutually exclusive, which is why envisioning the possibility of a critically affirmative politics of scholarly dialogue is so necessary today (for a related call for constructive critique, see Carmody et al., 2017). Yet what might such a 'generative critique' (Wright, 2017: 2) look like?

Surely there is not a one-size-fits-all approach to engaging in scholarly dialogue, since dialogues among 'friends' with whom one shares many affinities will likely take a considerably different form than dialogical encounters between 'adversaries'. It is relatively easy to take an affirmative stance with like-minded interlocutors within hermetically sealed interpretive communities. The real challenge, however, is maintaining such an affirmative ethics of care and mutuality when engaging in dialogues across the political divide. Indeed, it is quite rare for scholars on opposite sides of the political spectrum or university campus to even be willing to engage in a sustained dialogue, and, when such dialogical exchanges do occur, they often result in 'strange encounters' (Rose-Redwood vs. Smith, 2016). Yet, as Wright (2017: 2) argues, a generative critique 'does not shy away from difficult questions, of oneself or of others... [but instead] steps towards, rather than away from, uncomfortable positions'. In considering these issues, it is worth asking: What are the conditions of possibility and limits to critically affirmative dialogue across the political divide? What is the threshold beyond which scholarly dialogue is no longer possible or desirable? Additionally, in what ways is it possible for 'internal' critiques to strengthen, rather than sink, progressive scholarship? And doesn't the very distinction between 'internal' and 'external' critique have the effect of reifying the boundaries of 'community' in scholarly dialogue rather than viewing them as performative enactments of identification and subjectification which are themselves open to contestation and transformation?

\section{Geographies of public (dis)engagement: The possibilities and limits to dialogue in a polarized age}

As we've highlighted above, scholars engage in dialogues not only among themselves but with research participants, students, granting agencies, journalists, media pundits, policy-makers, nongovernmental organizations, grassroots activists, and many others, blurring the boundary between scholarly dialogue and 'real-world' action. Indeed, scholars are often charged with academic elitism if they do not partake in at least some form of public engagement and pursue 'impactful' research. Yet how geographers and other scholars conceive of, and interact with, the 'public' deserves greater attention (Staeheli and Mitchell, 2007). For instance, what sorts of power plays are at work when scholars and professionals make claims to 'expertise' (Kuus, 2014) as part of monological rhetorics of authoritative knowledge production and dissemination? To what extent have geographers actually moved beyond monological forms of scholarly engagement by embracing dialogical practices in their research, teaching, and service? And what are the limits to public dialogue in an age of intense and often vitriolic political polarization?

Since the radical turn in the discipline during the late-1960s, there have been numerous calls for geography to become more socially relevant (Dickinson and Clarke, 1972; Blowers, 1974) and socially responsible (Prince, 1971; Simmons et al., 1976). 
Moreover, others have advocated for geographers to undertake applied research of policy and practical value (Martin, 2001), and there have also been repeated calls for geography to move beyond the academy to practice activist and advocacy geography (Blomley, 1994; Chouinard, 1994; Derickson and Routledge, 2015; Fuller and Kitchin, 2004), public geographies (Kitchin et al., 2013), and to be generally 'publicly engaged' (Brewer, 2013). Such engagement can be through community-based and participatory action research (Etmanski et al., 2014; Kindon et al., 2007; Mason, 2015; Twamley et al., 2017) or through other praxes such as media and social media work (Kitchin et al., 2013). Recently, in the context of social and political change in a Trump-led United States, Alderman (2017) has once again drawn attention to the importance of public engagement and has called upon geographers to 'move beyond simply analyzing issues and problems' and instead contribute toward 'making informed and ethical interventions in how public groups understand, debate, and act on those problems'. Such efforts continue to be necessary in the current political climate as progressive scholarly practices and values are being threatened by incendiary claims made by chauvinist-populist leaders fomenting the negative passions of some elements of their electoral constituencies.

In recent years, we have witnessed a virulent re-emergence of the long-standing 'White rage' against African Americans, Latinos, and immigrants in the United States (Anderson, 2016), which has paved the way to the Trump era as well as a growing intolerance of incoming African and West Asian refugees across Europe (United Nations, 2016). The rise of ethno-nationalist extremism, however, is by no means confined to North America and Europe. In India, for instance, Hindu nationalist groups have attacked Muslim communities, committing horrific acts of communal violence (Khanna, 2008). Not surprisingly, members of the nationalist group Hindu Sena even held a prayer ritual ('havan') in support of Donald Trump's presidential campaign (Doshi, 2016), championing him as the 'savior of humanity' for his anti-Muslim views (Mogul, 2016). The killing, incarceration, and harassment of journalists via false charges of sedition for speaking out against Hindutva groups is also on the rise in India (Biswas, 2017). Similarly, in Bangladesh, the killing of journalists has increased (with five reported in 2015 alone) as well as harassment and murdering of bloggers who are seen to support secular beliefs and question the collusion of the state with Islamic fundamentalists (Mustafa, 2015). Academia has particularly come under assault in Turkey as the authoritarian regime of Recep Tayyip Erdoğan has purged educational institutions, firing thousands of university administrators, professors, and school teachers, and revoking the passports of academics in the wake of an attempted coup (Moreno, 2017). Globally, the Right is currently weaponizing academic speech while simultaneously seeking to delegitimize the value of scientific and humanistic scholarship alike, both of which have come under attack as antiintellectualism increasingly gains political traction.

The Right in general has placed progressive scholars in its crosshairs, and when a single tweet online can generate an avalanche of hateful counterspeech, ad hominem attacks, doxing, other forms of personal harassment by internet trolls, and a litany of 'alternative facts' and spurious or ill-(in)formed argument, the limits to dialogue in the era of social media become readily apparent. Within this hostile media environment, at what point should scholars actively disengage from certain public dialogues in order to ensure that they 'don't feed the trolls' (Sullivan, 2012)? This brings us back to the question of how scholars can best (dis)engage with extreme right-wing provocateurs on university campuses as well as in virtual and media spaces. To participate in dialogue requires a bare modicum of mutual respect between parties, and, in cases where this is lacking, the prospects of fruitful dialogue are very dim indeed. The stark paradox, then, is that at a time when public geographies and dialogues are increasingly necessary, the conditions of possibility for such dialogue are often lacking and thus encourage disengagement.

There are different strategies for disengaging in dialogue, ranging from ignoring a provocateur to aggressively seeking to shut down their public speech. The former may enable hate speech to go unchecked, whereas the latter often leads one 
directly into the trap set by the provocateur who seeks to paint themself as a defender of free speech against the illiberal forces of 'intolerance'. In such situations, how can university administrators, scholars, and students best respond to inflammatory, derogatory, and hateful speech masquerading as 'reasonable' discourse? One challenge in answering this question is that protesting against what Butler (1997) calls 'excitable speech' may inadvertently have the performative effect of bolstering a provocateur's public visibility and celebrity status. To preempt such an outcome, we must work toward developing critically affirmative strategies and tactics for challenging hate speech by embodying a hopeful politics that directs attention away from a provocateur's attention-seeking spectacle. This is, of course, easier said than done, but it offers the possibility of shifting the narrative in such a way that the purveyors of hate speech are literally 'upstaged' by their opponents, such as when 40,000 counter-protesters rallied against White supremacy in Boston on August 19, 2017, dramatically overshadowing the 'few dozen people' on the other side of the barricades $(C B C, 2017 \mathrm{a}$; LeBlanc, 2017), or when the Canadian politician Jagmeet Singh (now leader of Canada's New Democratic Party) responded to an anti-Muslim heckler with a message of 'love and courage' $(C B C, 2017 \mathrm{~b})$.

Considering the matter of 'dialogue' in human geography and in public life more generally raises all sorts of questions about the ethics and politics of dialogical encounters, only some of which we have touched on above. We have posed various questions throughout this article with the aim of stimulating discussion of the embodied practices of scholarly dialogue rather than presupposing that definitive answers are ready at hand. One of the tensions in such a discussion involves what Janz (2015: 484) calls the 'dual nature of dialogue', which refers to the fact that dialogue 'is both a concept in need of analysis ... [as well as] the precondition for the production of concepts'-and the worlds they help shape. We have suggested here that the very conditions of possibility for dialogue in human geography cannot be taken for granted, since the value of scholarly dialogue is not pregiven but is historically and geographically situated, emerging through contested processes of valuation. This is especially evident in circumstances where scholarly dialogue is actively devalued, such as when politicians seek to pass laws aiming to curtail particular types of scholarly research and dialogue, or when university administrators close specific academic units that apparently lack 'value', or increase workloads in ways that erode the capacity to think, read, write, or participate in collegial conversations. Moreover, the neoliberal imperatives within higher education institutions generally reward competition over cooperation by constructing elaborate incentive systems that pit colleagues against each other in the quest for 'merit' and 'distinction' rather than fostering collaborative academic spaces in which scholarly dialogue can flourish.

To be sure, there have been some efforts to challenge the individualizing and soul-crushing tendencies of the 'neoliberal university' (Mountz et al., 2015), not to mention opposing the racist, rightwing populism that is on the rise around the world (although it must be noted that many academics, especially in economics and business but also some in geography, hold neoliberal and right-wing views). A renewed practice of critically affirmative dialogue can play an important role in disrupting the perverse combination of individualism and ethnicmajority revanchism that characterizes the contemporary era. Engaging in deeper scholarly dialogues, however, requires time to listen to other voices that may disrupt the sameness of our own monological narratives and to think about the possible implications for our own work. This is particularly important because a good number of scholarly exchanges simply do 'not involve hearing at all... [since] many dialogues are little more than two speakers speaking in turn' (Janz, 2015: 486). The capacity to listen attentively is by no means a panacea, but it is nevertheless crucial to fostering dialogical spaces that can potentially enable the coproduction of geographical knowledge. The alternatives of continuing to talk past one another or cutting off communication altogether hardly seem like viable paths forward for geographical thought and practice, which is why it is still necessary to critically affirm both the possibilities and limits to dialogue in human geography today. 
However, seeking to cultivate a critically affirmative politics of dialogue is not a call to universally banish 'negativity' from scholarly discourse, nor does it presume that dialogical engagement is always the most productive response to disagreement and political conflict in a polarized age. Indeed, there are times and places when negation (and the negation of the negation, as the dialecticians put it) is most certainly required, and other instances when it is indeed necessary to disengage from dialogue altogether. Yet, from our perspective - which we have the privilege of being able to share here as this journal's editors - scholarly dialogue still has an important role to play in challenging the erosion of the value of scholarly and intellectual pursuits with the rise of 'alternative' facts, 'fake' news, and false moral equivalences as well as working to contest social and environmental injustices within increasingly exclusionary capitalist societies. At the same time, there remain many questions about scholarly and publicly engaged dialogue that themselves require attention, debate, and dialogue. We look forward to engaging with others in the geographical community to tackle those questions as well as refine and/or challenge the thoughts we have laid out in the present article.

\section{Acknowledgements}

The authors would like to thank Mark Boyle, Barry Fruchter, Mary Gilmartin, Michael Glass, Maral Sotoudehnia, Simon Springer, and Farhana Sultana for feedback on the initial draft of this manuscript.

\section{Declaration of Conflicting Interests}

The author(s) declared no potential conflicts of interest with respect to the research, authorship, and/or publication of this article.

\section{Funding}

The author(s) received no financial support for the research, authorship, and/or publication of this article.

\section{References}

ACME Resistance (2018) Geographers against Trump: reflections on the first annual ACME protest. ACME: An International Journal for Critical Geographies 17(1): 1-16.
Alderman D (2017) The serious business of public communication. Newsletter of the American Association of Geographers. Available at: http://news.aag.org/2017/ 08/the-serious-business-of-public-communication (accessed 1 August 2017).

Anderson C (2016) White Rage: The Unspoken Truth of Our Racial Divide. New York: Bloomsbury.

Bakhtin M (1981) The Dialogic Imagination (Holquist $\mathrm{M}$ ed.). Austin: University of Texas Press.

Barkan J and Pulido L (2017) Justice: an epistolary essay. Annals of the American Association of Geographers 107(1): 33-40.

Barry A and Maslin M (2016) The politics of the anthropocene: a dialogue. Geo: Geography and Environment 3(2): 1-12.

Beer D (2013) Popular Culture and New Media: The Politics of Circulation. Basingstoke: Palgrave Macmillan.

Bell D (1995) [screw]ING GEOGRAPHY (censor's version). Environment and Planning D: Society and Space 13(2): 127-131.

Biswas S (2017) Obituary: the fearless journalist-activist Gauri Lankesh. BBC News, 6 September. Available at: http://www.bbc.co.uk/news/world-asia-india41172115 (accessed 6 September 2017).

Blomley N (1994) Activism and the academy. Environment and Planning D: Society and Space 12(4): 383-385.

Blowers AT (1974) Relevance, research and the political process. Area 6(1): 32-36.

Bouattla M (2017) The narrative on university safe spaces and no platform policies couldn't be further from the truth. Huffington Post, 10 February. Available at: http://www.huffingtonpost.co.uk/ malia-bouattia/free-speech-campus-safe-spaces_b_ 14678920.html (accessed 10 February 2017).

Brewer J (2013) Toward a publicly engaged geography: polycentric and iterated research. Southeastern Geographer 53(3): 328-347.

Brulle R (2010) From environmental campaigns to advancing the public dialog: environmental communication for civic engagement. Environmental Communication 4(1): 82-98.

Butler J (1997) Excitable Speech: A Politics of the Performative. New York: Routledge.

Carmody P, Corbera E, Fletcher R, et al. (2017) What's left? The role of critical scholarship in a Trumpian age. Geoforum 85: 316-317. 
$C B C$ (2017a) March against racism drowns out 'free speech' rally in Boston. $C B C$ News, 19 August. Available at: http://www.cbc.ca/news/world/anti-racismrally-boston-1.4254282 (accessed 19 August 2017).

$C B C$ (2017b) Jagmeet Singh responds to persistent heckler with message of love. $C B C$ News, 9 September. Available at: http://www.cbc.ca/news/canada/ jagmeet-singh-responds-to-heckler-1.4282702 (accessed 9 September 2017).

Chouinard V (1994) Editorial: reinventing radical geography: Is all that's left right? Environment and Planning D: Society and Space 12(1): 2-6.

Daniels S and Bartlein P (2017) Charting time. Annals of the American Association of Geographers 107(1): 28-32.

Dear M (2001) The politics of geography: hate mail, rabid referees, and culture wars. Political Geography 20(1): $1-12$.

Demeritt D and Dyer S (2002) Dialogue, metaphors of dialogue and understandings of geography. Area 34(3): 229-241.

Derickson K (2017) Theorizing racial justice and the city: learning from the 'Tuvel affair'. International Journal of Urban and Regional Research. Available at: http:// www.ijurr.org/spotlight-on-overview/race-justiceand-the-city/derickson (accessed 15 June 2018).

Derickson K and Routledge P (2015) Resourcing scholar-activism: collaboration, transformation, and the production of knowledge. The Professional Geographer 67(1): 1-7.

Dialogues in Human Geography (2018) Aims \& scope. Available at: https://us.sagepub.com/en-us/nam/ journal/dialogues-human-geography\#aims-and-scope (accessed 15 June 2018).

Dickinson JP and Clarke CG (1972) Relevance and the 'newest geography'. Area 4(1): 25-27.

Domosh M (2017) Radical intradisciplinarity: an introduction. Annals of the American Association of Geographers 107(1): 1-3.

Doshi V (2016) 'He's our hero': Hindu nationalists rally for Donald Trump in India. The Guardian, 13 May. Available at: https://www.theguardian.com/us-news/ 2016/may/13/donald-trump-india-hindu-supportersnew-delhi (accessed 13 May 2016).

Esson J, Noxolo P, Baxter R, et al. (2017) The 2017 RGS-IBG chair's theme: Decolonising geographical knowledges, or reproducing coloniality? Area 49(3): 384-388.

Etmanski C, Hall B and Dawson T (eds) (2014) Learning and Teaching Community-Based Research: Linking Pedagogy to Practice. Toronto: University of Toronto Press.

Flaherty C (2017) Resignations at 'Third World Quarterly'. Inside Higher Ed, 20 September. Available at: https://www.insidehighered.com/news/2017/09/20/ much-third-world-quarterlys-editorial-board-resignssaying-controversial-article (accessed 20 September 2017).

Foucault M (1984) Polemics, politics, and problematizations: an interview with Michel Foucault. In: Rabinow P (ed), The Foucault Reader. New York: Pantheon, pp. 381-390.

Friess D and Jazeel T (2017) Unlearning 'landscape'. Annals of the American Association of Geographers 107(1): 14-21.

Fuller D and Kitchin R (2004) Radical theory/critical praxis. In: Fuller D and Kitchin R (eds), Radical Theory, Critical Praxis: Making a Difference Beyond the Academy? Kelowna: Praxis E-Press, pp. 1-20.

Garcia-Ramon MD (2004) The spaces of critical geography: an introduction. Geoforum 35(5): 523-524.

Gillard R (2016) Unravelling the United Kingdom's climate policy consensus: the power of ideas, discourse and institutions. Global Environmental Change 40(Supplement C): 26-36.

Gurevitch Z (2000) Plurality in dialogue: a comment on Bakhtin. Sociology 34(2): 243-263.

Harrison S, Massey D, Richards K, et al. (2004) Thinking across the divide: perspectives on the conversations between physical and human geography. Area 36(4): 435-442.

Hart P and Nisbet E (2012) Boomerang effects in science communication: How motivated reasoning and identity cues amplify opinion polarization about climate mitigation policies. Communication Research 39(6): 701-723.

Harvey D (2017) 'Listen, anarchist!' A personal response to Simon Springer's 'Why a radical geography must be anarchist'. Dialogues in Human Geography 7(3): 233-250.

Howarth C and Sharman A (2015) Labeling opinions in the climate debate: a critical review. Wiley 
Interdisciplinary Reviews: Climate Change 6(2): 239-254.

Jago R (2017) In defence of ad hominem. CANADA$L A N D, 28$ September. Available at: http://www. canadalandshow.com/in-defence-of-ad-hominem (accessed 28 September 2017).

Janz B (2015) Philosophy-in-place and the provenance of dialogue. South African Journal of Philosophy 34(4): 480-490.

Khanna R (2008) Communal violence in Gujarat, India: impact of sexual violence and responsibilities of the health care system. Reproductive Health Matters 16(31): 142-152.

Kindon S, Pain R and Kesby M (eds) (2007) Participatory Action Research Approaches and Methods: Connecting People, Participation and Place. London: Routledge.

Kitchin R, Linehan D, O'Callaghan C, et al. (2013) Public geographies and social media. Dialogues in Human Geography 3(1): 56-72.

Kobayashi A and Peake L (1994) Unnatural discourse: 'race' and gender in geography. Gender, Place and Culture 1(2): 225-243.

Kuus M (2014) Geopolitics and Expertise: Knowledge and Authority in European Diplomacy. Chichester: Wiley Blackwell.

Lave R, Wilson M, Barron E, et al. (2014) Intervention: critical physical geography. The Canadian Geographer 58(1): 1-10.

Lawson V (2007) Geographies of care and responsibility. Annals of the Association of American Geographers 97(1): 1-11.

LeBlanc S (2017) Massive counterprotest against white nationalism upstages 'free speech rally' in Boston. Chicago Tribune, 20 August. Available at: http:// www.chicagotribune.com/news/nationworld/ctboston-free-speech-rally-20170819-story.html (accessed 20 August 2017).

Liu C and Sui D (2017) Exploring the spatiotemporal pattern of cyberbullying with Yik Yak. The Professional Geographer 69(3): 412-423.

Longhurst R (2017) Skype: Bodies, Screens, Space. New York: Routledge.

Mahtani M (2014) Toxic geographies: absences in critical race thought and practice in social and cultural geography. Social \& Cultural Geography 15(4): 359-367.
Mansfield B and Doyle M (2017) Nature: a conversation in three parts. Annals of the American Association of Geographers 107(1): 22-27.

Martin R (2001) Geography and public policy: the case of the missing agenda. Progress in Human Geography 25(2): 189-210.

Mason K (2015) Participatory action research: coproduction, governance and care. Geography Compass 9(9): 497-507.

Massey D (1999) Space-time, 'science' and the relationship between physical geography and human geography. Transactions of the Institute of British Geographers 24(3): 261-276.

McKittrick K (2006) Demonic Grounds: Black Women and the Cartographies of Struggle. Minneapolis: University of Minnesota Press.

McLean J and Maalsen S (2013) Destroying the joint and dying of shame? A geography of revitalised feminism in social media and beyond. Geographical Research 51(3): 243-256.

Meldrum H, Szymanski D, Oches E, et al. (2017) Speaking out or staying quiet on climate change: broadcast meteorologists influenced by the need to be pithy, popular and politically cautious. In: Leal Filho W and Keenan J (eds), Climate Change Adaptation in North America: Fostering Resilience and the Regional Capacity to Adapt. Berlin: Springer, pp. 261-277.

Mogul P (2016) India's right-wing Hindu Sena throws Donald Trump birthday party in New Delhi. International Business Times, 14 June. Available at: http:// www.ibtimes.co.uk/indias-right-wing-hindu-senathrows-donald-trump-birthday-party-new-delhi1565370 (accessed 14 June 2017).

Moreno S (2017) Turkish crackdown takes toll on academic output. Chemistry World, 4 August. Available at: https://www.chemistryworld.com/news/turkishcrackdown-takes-toll-on-academic-output/3007804. article (accessed 4 August 2017).

Moss P (2014) Some rhizomatic recollections of a feminist geographer: working toward an affirmative politics. Gender, Place \& Culture 21(7): 803-812.

Mott C and Cockayne D (2017) Citation matters: mobilizing the politics of citation toward a practice of 'conscientious engagement'. Gender, Place \& Culture 24(7): 954-973. 
Mouffe C (1993) The Return of the Political. London: Verso.

Mouffe C (2013) Agonistics: Thinking the World Politically. London: Verso.

Mountz A, Bonds A, Mansfield B, et al. (2015) For slow scholarship: a feminist politics of resistance through collective action in the neoliberal university. ACME: An International Journal for Critical Geographies 14(4): 1235-1259.

Mustafa S (2015) Bangladesh bloggers: clear pattern to killings. BBC News, 12 May. Available at: http:// www.bbc.co.uk/news/world-asia-32708975 (accessed 12 May 2015).

Natter W (2001) From hate to antagonism: toward an ethics of emotion, discussion and the political. Political Geography 20(1): 25-34.

Parker B (2017) The feminist geographer as killjoy: excavating gendered urban power relations. The Professional Geographer 69(2): 321-328.

Peake L (2016) On feminism and feminist allies in knowledge production in urban geography. Urban Geography 37(6): 830-838.

Prince HC (1971) Questions of social relevance. Area 3(3): 150-153.

Qadir S (2017) Responding to the viewpoint article on 'The Case for Colonialism'. Available at: http:// www.tandfonline.com/pb-assets/TWQ-responseSept-2017.pdf (accessed 26 September 2017).

Rickards L (2015) Critiquing, mining and engaging anthropocene science. Dialogues in Human Geography 5(3): 337-342.

Rickards L, Wiseman J and Kashima Y (2014) Barriers to effective climate change mitigation: the case of senior government and business decision makers. Wiley Interdisciplinary Reviews: Climate Change 5(6): 753-773.

Robinson J (2003) Postcolonising geography: tactics and pitfalls. Singapore Journal of Tropical Geography 24(3): 273-289.

Robinson N (2017) A quick reminder of why colonialism was bad. Current Affairs, 14 September. Available at: https://www.currentaffairs.org/2017/09/a-quickreminder-of-why-colonialism-was-bad (accessed 14 September 2017).

Roelofs P and Gallien M (2017) Clickbait and impact: How academia has been hacked. LSE Impact Blog, 19 September. Available at: http://blogs.lse.ac.uk/ impactofsocialsciences/2017/09/19/clickbait-andimpact-how-academia-has-been-hacked (accessed 19 September 2017).

Rose G (1993) Feminism and geography: the limits of geographical knowledge. Minneapolis, MN: University of Minnesota Press.

Rose G (2016) Cultural geography going viral. Social \& Cultural Geography 17(6): 763-767.

Rose-Redwood R vs Smith J (2016) Strange encounters: a dialogue on cultural geography across the political divide. Journal of Cultural Geography 33(3): 356-378.

SAGE Publishing (2018) Ethics \& responsibility. Available at: https://us.sagepub.com/en-us/nam/ethicsresponsibility (accessed 15 June 2018).

Schmitt C (2007 [1932]) The Concept of the Political. Chicago: University of Chicago Press.

Sheppard E and Plummer P (2007) Toward engaged pluralism in geographical debate. Environment and Planning A 39(11): 2545-2548.

Simmons I, Smith D, Colenutt B, et al. (1976) To what extent is the geographer's world the 'real world'? Area 8(2): 82-86.

Smith R (2006) Peer review: a flawed process at the heart of science and journals. Journal of the Royal Society of Medicine 99(4): 178-182.

Springer S (2017) The limits to Marx: David Harvey and the condition of postfraternity. Dialogues in Human Geography 7(3): 280-294.

Staeheli L and Mitchell D (2007) Locating the public in research and practice. Progress in Human Geography 31(6): 792-811.

Sullivan N (2012) Don't feed the trolls. O'Reilly Fluent Conference: JavaScript \& Beyond. Available at: https://www.youtube.com/watch?v=ulNS1ES1Fds (accessed 30 May 2012).

Sultana F (2017) Petition to raise academic publishing standards. Email to http://caglist@lists.uvic.ca, 13 September.

Tadaki M (2017) Rethinking the role of critique in physical geography. The Canadian Geographer 61(1): 73-83.

Taylor and Francis Group (2017) Addressing 'The Case for Colonialism' viewpoint essay. 26 September. Available at: http://www.tandfonline.com/pb-assets/ TWQ-response-Sept-2017.pdf (accessed 26 September 2017). 
Thomas R (2017) Journal's editorial board resigns over colonialism essay. Times of India, 19 September. Available at: http://timesofindia.indiatimes.com/ world/uk/journals-editorial-board-resigns-overcolonialism-essay/articleshow/60754617.cms (accessed 19 September 2017).

Twamley K, Rosen R and Mayall B (2017) The (im)possibilities of dialogue across feminism and childhood scholarship and activism. Children's Geographies 15(2): 249-255.

Underhill-Sem Y (2017) Academic work as radical practice: getting in, creating a space, not giving up. Geographical Research 55(3): 332-337.

United Nations (2016) Intolerance and xenophobia on the rise in Europe. Brussels: United Nations Regional
Information Centre for Western Europe, 15 November. Available at: http://www.unric.org/en/ latest-un-buzz/30377-intolerance-and-xenophobia-onthe-rise-in-europe (accessed 15 November 2016).

Valentine G (1998) 'Sticks and stones may break my bones': a personal geography of harassment. Antipode 30(4): 305-332.

Wilson M and Starkweather S (2014) Web presence of academic geographers: a generational divide? The Professional Geographer 66(1): 73-81.

Women and Geography Study Group (1997) Feminist Geographies: Explorations in Diversity and Difference. Harlow: Longman.

Wright S (2017) Critique as delight, theory as praxis, muckin in. Geographical Research 55(3): 338-343. 